\title{
CHOQUET THEORY FOR SIGNED MEASURES
}

\author{
CONSTANTIN P. NicUlescu
}

Abstract. We introduce the notion of barycenter for a class of non-necessarily positive Radon measures and prove on this basis several inequalities which extend classical results such as Steffensen's inequality, Fink's version of the Hermite-Hadamard inequality, Fuchs 'extension of the majorization inequality of Hardy-Littlewood-Polýa etc.

Mathematics subject classification (2000): 26D15, 46A55, 26A51, $26 \mathrm{~B} 55$.

Key words and phrases: convex function, barycenter, Choquet theory.

\section{REFERENCES}

[1] E. M. ALfSEN, Compact convex sets and boundary integrals, Springer-Verlag, Berlin, 1971.

[2] S. S. DRAGOMIR, On Hadamard's inequality for the convex mappings defined on a ball in the space and applications, Math. Inequal. \& Appl., 3 (2000), 177-187.

[3] A. M. FINK, A best possible Hadamard inequality, Math. Inequal. \& Appl., 1 (1998), 223-230.

[4] L. Fuchs, A new proof of an inequality of Hardy, Littlewood and Polya, Mat. Tidsskr. B., 1947, pp. 53-54.

[5] J. HADAMARD, Étude sur les propriétés des finctions entières et en particulier d'une fonction considerée par Riemann, J. Math. Pures Appl., 58 (1893), 171-215.

6] L. LuPAş, Problem E3322, Amer. Math. Month., 96 (1989), p. 357.

[7] D. S. Mitrinović, Analytic Inequalities, Springer-Verlag, 1970.

[8] D. S. Mitrinović AND I. B. LACKOvić, Hermite and convexity, Aequationes Mathematicae, 28 (1985), 229-232.

[9] C. P. NiCULESCU, The Hermite-Hadamard inequality for functions of a vector variable, Math. Inequal. \& Appl., to appear.

[10] C. E. M. PEARCE AND S. S. DRAGOMIR, Selected topics on Hermite-Hadamard Inequality and Applications, Victoria University, Melbourne, 2000.

[11] R. R. Phelps, Lectures on Choquet's Theorem, D. van Nostrand Company Inc., Princeton, 1966.

[12] T. Popoviciu, Notes sur les fonctions convexes d'ordre superieur (IX), Bull. Math. Soc. Roum. Sci., 43 (1941), 85-141.

[13] A. W. Roberts and D. E. VArberg, Convex functions, Academic Press, New York and London, 1973.

[14] J. F. STEFFENSEN, On certain inequalities and methods of approximation, J. Inst. Actuaries, 51 (1919), 274-297. 